\title{
PELAKSANAAN LAYANAN BIMBINGAN UNTUK MENGATASI ANAK YANG MALAS BELAJAR
}

\author{
Astri Putri Adinda ${ }^{1}$, Annisa Nur Faizah Gaos ${ }^{2}$, Rina Siti Nur Fatimah ${ }^{3}$ \\ Universitas Muhammadiyah Tangerang \\ astriputriaaa@gmail.com,Annisafaizah0@gmail.com
}

\begin{abstract}
This study aims to resolve the problem of students who are lasy to learn, a teacher is required to classify the type of laziness that is descending on students and students in class I SDIT Arya Cendikia. This study uses a qualitative approach with the subject of the first grade teacher research. The research instruments used were interviews, documentation, observation, field notes and questionnaires. The steps of data analysis include data reduction, data presentation, and verification. Checking the validity of the data using triangulation techniques. The results showed that the teacher had not yet created a tutoring service program. Tutoring services are carried out by the teacher according to his understanding. Tutoring services by teachers are understood as a form of assistance for students to achieve learning outcomes according to targets set. In implementing tutoring services, teachers experience obstacles including limited understanding, time, and skills.
\end{abstract}

Keywords : Mentoring Services, Layy Learning

\begin{abstract}
Abstrak: Penelitian ini bertujuan untuk menyelesaikan permasalahan peserta didik yang malas belajar, seorang guru di tuntut untuk mengklasifikan jenis kemalasan yang sedang menghinggapi para siswa maupun siswi di kelas I SDIT Arya Cendikia. Penelitian ini menggunakan pendekatan kualitatatif dengan subjek penelitian guru kelas I. Instrumen penelitian yang digunakan adalah wawancara, dokumentasi, observasi, catatan lapangan dan angket. Langkah-langkah analisis data meliputi reduksi data, penyajian data, dan verifikasi. Pemeriksaan keabsahan data menggunakan triangulasi teknik. Hasil penelitian menunjukkan bahwa guru belum guru sesuai dengan pemahaman nya. Layanan bimbingan belajar oleh guru dipahami sebagai suatu bentuk bantuan bagi siswa untuk mencapai hasil belajar sesuai target yang ditetapkan. Dalam melaksanakan layanan bimbingan belajar, guru mengalami hambatan antara lain keterbatasan pemahaman, waktu, serta keterampilan.
\end{abstract}

Kata Kunci : Layanan Bimbingan, Malas Belajar

Islamika : Jurnal Keislaman dan Ilmu Pendidikan

Volume 2, Nomor 1, Januari 2020; 170-175

https:// ejournal.stitpn.ac.id/index.php/islamika 


\section{PENDAHULUAN}

Bower berpendapat bahwa dengan Belajar kita dapat menunjukan adanya perubahan yang relatif dalam perilaku yang terjadi karena adanya beberapa pengalaman yang telah dialami dan juga latihan yang sudah dilakukan dalam waktu sebelumnya. Bower juga menjelaskan bahwa "Learning is a cognitive process" yang artinya Belajar adalah suatu proses kognitif. Disini Bower menjelaskan proses merupakan hal yang lebih penting dibandingkan hasil dari belajar itu sendiri (Bower ,1987: 150). Belajar merupakan sebuah proses usaha yang telah dilakukan oleh masing-masing individu untuk bisa memperoleh sebuah perubahan tingkah laku yang baru secara keseluruhan. Selain itu belajar sebagai hasil pengalaman individu itu sendiri dalam interaksi dengan lingkungannya. Bagi Moh. Surya, belajar kembali pada masingmasing personalnya untuk mau belajar dan mengerti hasil yang bisa didapat dari belajar itu sendiri (Moh. Surya, 1981: 32).

\section{METODE PENELITIAN}

\section{Jenis Penelitian}

Penelitian ini menggunakan jenis penelitian kualitatif. Dalam penelitian ini, peneliti mengumpulkan data deskriptif yang diperoleh dari pengumpulan data dengan pendekatan kualitatif yang dituangkan dalam bentuk kata-kata.

\section{Tempat dan Waktu Penelitian}

Penelitian ini dilaksanakan di SDIT Arya Cendikia Desa Sukamantri Kecamatan Pasar Kemis Kabupaten Tangerang pada semester genap tahun ajaran 2018/2019. Lokasi tersebut dipilih berdasarkan pertimbangan peneliti karena pelaksanaan layanan bimbingan dan konseling khususnya layanan bimbingan belajar di SDIT Arya Cendikia belum berjalan secara optimal karena layanan bimbingan konseling di SD dijalankan oleh guru kelas yang terpadu dengan proses pembelajaran.

\section{Subjek Penelitian}

Subjek dalam penelitian ini adalah guru kelas I SDIT Arya Cendikia. Guru kelas dijadikan subjek penelitian utama informan kunci karena sebagai pelaksana 
bimbingan dan konseling terutama layanan bimbingan belajar. Selain itu, guru kelas juga dipandang sebagai orang yang benar-benar mengetahui tentang data yang akan dikumpulkan. Selanjutnya kepala sekolah, guru, dan beberapa siswa kelas I juga dijadikan sumber informasi untuk mendapatkan data dan informasi sebanyakbanyaknya.

\section{Sumber Data}

Sumber data dalam penelitian ini adalah orang sebagai narasumber dan dokumen sebagai data pendukung. Dalam penelitian ini, narasumber yang dipilih oleh peneliti adalah guru kelas I, kepala sekolah, guru mata pelajaran dan beberapa siswa kelas I. Data pendukung dalam penelitian ini adalah dokumen yang terkait dengan subjek penelitian.

\section{Teknik Pengumpulan Data}

Teknik pengumpulan data dalam penelitian menggunakan teknik observasi, wawancara, dokumentasi, angket, dan catatan lapangan. Teknik pengumpulan data dalam penelitian ini dengan melakukan wawancara terhadap kelas I dan kemudian melakukan observasi pelaksanaan layanan bimbingan belajar dikelas I. Peneliti juga melakukan dokumentasi dan membuat catatan lapangan sebagai upaya untuk kelengkapan data.

\section{Instrumen Penelitian}

Dalam penelitian ini peneliti menjadi instrumen penelitian karena peneliti merupakan instrumen yang efektif untuk mengumpulkan data. Peneliti dibantu dengan instrumen panduan seperti panduan observasi (pengamatan), pedoman wawancara, lembar angket, catatan lapangan dan dokumentasi.

\section{Teknik Analisis Data}

Dalam teknik analisis ini terdapat tiga tahapan, yaitu reduksi data, penyajian data, dan verifikasi data. Data tersebut dihasilkan dari proses observasi, wawancara, dokumentasi, catatan lapangan, dan kuesioner. Proses selanjutnya adalah penyajian data. Penyajian data merupakan proses penampilan data secara lebih sederhana dalam bentuk paparan naratif dari hasil penelitian tentang pelaksanaan layanan bimbingan belajar pada siswa kelas I SDIT Arya Cendikia. Kemudian langkah terakhir adalah 
verifikasi data. Data yang telah diproses kemudian ditarik kesimpulan. Penyimpulan merupakan proses pengambilan intisari data sajian yang telah terorganisir dalam bentuk pernyataan kalimat yang singkat dan padat tetapi mengandung pengertian yang luas. Hasil analisis disusun untuk mengungkap realita pelaksanaan layanan bimbingan belajar pada siswa kelas I SDIT Arya Cendikia.

\section{Keabsahan Data}

Pada penelitian ini, pemeriksaan keabsahan data menggunakan cara triangulasi, yaitu teknik observasi wawancara dan dokumen. Langkah ini dilakukan untuk menguji kredibilitas data dan dilakukan dengan cara mengecek data kepada sumber yang sama dengan teknik yang berbeda. Dalam penelitian ini teknik triangulasi dilakukan dengan cara mengecek data dengan sumber yang sama dengan teknik yang berbeda yaitu observasi, wawancara, catatan lapangan, dan dokumentasi.

\section{HASIL PENELITIAN DAN PEMBAHASAN}

Penelitian ini dilakukan di SDIT Arya Cendikia, Tangerang. Untuk dapat menunjang keberhasilan pelaksanaan program bimbingan dan konseling khususnya layanan bimbingan belajar dibutuhkan biaya dan fasilitas pendukung. Karena program layanan bimbingan dan konseling disekolah tersebut belum disusun.Untuk itu guru juga harus melaksanakan pengajaran perbaikan pada siswa, tujuannya untuk memperbaiki kesalahan siswa dalam proses dan hasil belajar mereka yang diberikan kepada seseorang atau sekelompok siswa yang membutuhkan. Sasaran utamanya adalah siswa siswa yang mengalami kesulitan belajar contohnya anak pada anak yang malas karena mereka sulit untuk berkonsentrasi. Namun dalam pelakasanaannya ini diberikan pada semua siswa.Selain kegiatan perbaikan, guru juga melaksanakan pengayaan. Pelaksanaan pengayaan diberikan oleh guru sejalan dengan prngajaran perbaikan. Dalam hal ini siswa diberikan soal-soal bagi nilainya yang dibawah kkm. Untuk meningkatkan motivasi belajar, guru juga memberikan teguran atau nasehat kepada siswa. Dalam mengembangkan sikap dan kebiasaan belajar yang baik, guru juga lebih menekankan pada pemberian motivasi belajar. Hasil penelitian 
menunjukkan bahwa di SDIT Arya Cendikia belum disusun program layanan bimbingan belajar yang dilaksanakan oleh guru kelas dengan proses pembelajaran. Berdasarkan hasil penelitian telah dijelaskan bahwa pelaksanaan layanan bimbingan belajar pada umumnya untuk membantu siswa di SDIT Arya Cendikia dalam meningkatkan prestasi belajarnya.

Menurut Juntika $(2006,52)$ dijelaskan bahwa pelaksanaan layanan bimbingan belajar di SD membantu siswa dalam mengembangkan kebiasaan belajar yang baik untuk menguasai pengetahuan dan keterampilan serta menyiapkannya melanjutkan pendidikan ke tingkat yang lebih tinggi. Diharapkan dengan mempunyai kebiasaan belajar yang baik, siswa dapat meningkatkan prestasi belajar.Tujuan utama dari adanya pelaksanaan layanan bimbingan belajar adalah terhindarnya siswa dari kesulitan belajar, sehingga siswa dapat optimal untuk mengembangkan potensi yang dimiliki (Juntika, 2006:15). Jika siswa terhindar dari kesulitan belajar maka siswapun dapat mengembangkan aspek pribadi sosial dan dapat merencanakan karir yang sesuai dengan kondisi dirinya sendiri.Dalam penelitian ini bahwa pelaksanaan layanan bimbingan belajar dapat mengurangi kesulitan belajar siswa di sekolah tersebut. Hal ini ditunjukkan dengan adanya peningkatan nilai yang diperoleh dan dapat mengerjakan maupun mengumpulkan tugas. Dapat dikatakan bahwa tujuan dari layanan bimbingan belajar sudah tercapai yaitu dengan terhindarnya dari kesulitan belajar yang dialami dan dapat mengembangkan kebiasaan belajar yang baik.

Berdasarkan penelitian Hardesty dan Dillard (1994, Gibson \& Mitchell, 2011:80) terdapat tiga perbedaan utama dalam aktivitas konselor di jenjang pendidikan (SD, SMP, SMA), yaitu (a) konselor SD lebih banyak terlibat dalam aktivitas konsultasi dan koordinasi; (b) konselor SD lebih sedikit melakukan aktivitas administratif; (c) konselor SMP dan SMA lebih menangani konseling berbasis individu kliennya, sedangkan konselor SD menangani konseling secara sistematis bersama keluarga, guru dan lingkungan sekitar. Penemuan tersebut lebih menegaskan kembali bahwa peranan konselor SD berbeda dengan konselor di jenjang pendidikan menengah. 


\section{KESIMPULAN}

Berdasarkan hasil penelitian dan pembahasan yang diperoleh tentang pelaksanaan layanan bimbingan belajar pada siswa kelas I di SDIT Arya Cendikia dapat disimpulkan bahwa hasil yang diperoleh dari pelaksanaan layanan bimbingan belajar tersebut ditunjukkan dengan perubahan yang terjadi pada siswa yang bersangkutan. Perubahan tersebut meliputi adanya peningkatan prestasi belajar baik dari nilai harian maupun nilai ulangan, mengerjakan dan mengumpulkan tugas tepat waktu, dan dapat berkonsentrasi dengan memperhatikan pelajaran yang diberikan oleh guru. Oleh karena itu keterampilan dari wali kelas tersebut dalam memberikan layanan bimbingan belajar sangat diperlukan.

Berdasarkan kesimpulan tersebut, maka pelaksanaan layanan bimbingan belajar dalam mengurangi kesulitan belajar akan lebih baik lagi jika dalam pelaksanaannya dilanjutkan dengan lebih mempersiapkan materi-materi bimbingan yang terkini dan sesuai dengan karakteristik siswa yang bersangkutan. Selain itu juga perlu diberikan layanan bimbingan belajar dengan berbagai metode yang sesuai dengan kebutuhan dan karakteristik siswa.

\section{DAFTAR PUSTAKA}

Abdurrahman, M. 2003. Pendidikan Bagi Anak Berkesulitan Belajar.Jakarta: Rineka Cipta.

Ahmadi, A., \& Supriyono., W. 2001. Psikologi Belajar. Jakarta: Rineka Cipta.

Dalyono, M. 1997. Psikologi Pendidikan. Jakarta: PT. Rineka Cipta.

Hellen. 2005. Bimbingan dan Konseling. Ciputat: Quantum Teaching. Hellen. 2002. Bimbingan dan Konseling dalam Islam. Jakarta: Ciputat Press.

Moleong, L. J. 2007. Metodologi Penelitian Kualitatif. Bandung: PT. Jakarta: UPI.Press. 